\title{
導電性高分子の基礎と応用
}

\author{
黄 允彦*, 宮田 清蔵*
}

\section{Introduction of Conducting Polymer and Its Promising Applications.}

\author{
Yuneon WHANG * and Seizou MIYATA *
}

*東京農工大学工学部物質生物工学科（勇184 東京都小金井市中町2-24-16）

* Division of Chemical and Biological Science and Technology, Faculty of Technology, Tokyo University of Agriculture \& Technology (2-14-16 Nakamachi, Koganei-shi, Tokyo 184)

\section{1.はじめに}

非金属でありながら金属のような電気伝導性をも つ物質として19世紀中ごろ合成されたテトラシアノ 白金酸塩，1910年にBurtらによって合成されたポリ 硫化窒素（SN)xなど，金属以外の導電性を示す物 質の研究の歴史はかなり長いが，現在のような活発 な研究が始まったのは1970年代の後半からである。 すなわち有機高分子であるポリアセチレンが白川ら によってフィルム状に合成され ${ }^{1)}$ ，その導電率が電子 受容体であるヨウ素（ $\mathrm{I}_{2}$ ) のドーピングにより数ケ夕 も増加し，導電体領域まで至ることが発表されたと きからである゙2。

数十年間優れた電気絶縁材料として実用面でその 座を確保してきた有機高分子が導電材料として浮上 したことは, 驚きであり, 活発な研究の対象となる のに十分であった。また学問的には新しい概念の導 入が必要とされ，産業界においてはすでに知られて いる高分子の材料としての長所に電気的特性が付与 された新規材料の商品化への可能性が期待された。

本解説では導電性高分子の導電メカニズムの簡単 な説明，およびその応用 (研究) 分野についていく つか紹介する。

\section{2. 導電性高分子の導電機構}

\section{1 様々な導電性高分子の構造および特徵}

ポリアセチレンをはじめ様々な導電性高分子がこ
の十数年にわたって開発されてきた。図 1 に代表的 な導電性高分子の構造を示す。図 1 からわかるよう に導電性高分子となるには主鎖が $\pi$ 電子が分子全体 にひろがる共役二重結合の構造をとらなければなら ない。なぜなら，匹電子が分子全体に広がるのに伴っ て電子は容易に励起され（バンドギャップが小さく なる)，電荷キャリアとして働くことができるからで ある。したがって， $\pi$ 共役構造がどれくらい長くつな がっているかということは，導電性高分子の真性導 電率と直接関係するバンドギャップを決定する。し かし，このような理論は導電性高分子の $\pi$ 電子雲が平 面状になっているときに限る。実際の導電性高分子 においては電子雲は平面状になっておらず（グラファ イトのような構造をもつラダーおよびネットワーク 状高分子は平面状)，そのずれは化学構造によって異 なる。

Brédas らは様々な導電性高分子の化学構造に基づ いてバンドギャップ，バンド幅などのバンドパラメー タをVEH (Valence Effective Hamiltonian) 理論 を用いて計算した（表 1 ） ${ }^{3)}$ 。このバンドパラメータ は導電性高分子の導電性扔よび酸化・還元特性など を予想するときにかなり重要な目安となる。例えば, ポリピロールの場合はイオン化ポテンシャルが低く $(3.9 \mathrm{eV})$ ，電子親和力も低い $(0.3 \mathrm{eV})$ ことから 電子受容体によって酸化されやすいが, 電子供与体 による還元はかなり起こりにくいことがわかる。

導電性高分子は $\pi$ 電子間の強い相互作用のために分 
(a)

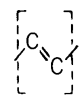

(b)

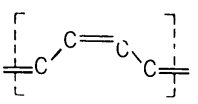

(d)

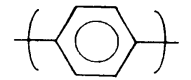

(e)<smiles>CCCCCCCC=Cc1ccc(C(C)(I)I)cc1</smiles>

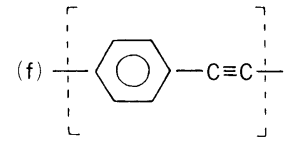

h)

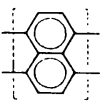

(i)

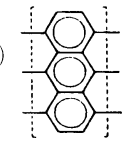

(j)<smiles>Cc1ccc(I)[nH]1</smiles>

(k)<smiles>Cc1c(I)[nH]c(I)c1C</smiles>

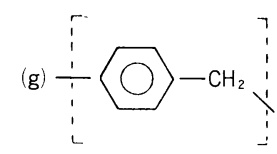

(c) $\frac{5}{2} c$ " $c-c=\frac{?}{!}$

(g)

(a) trans-polyacetylene

(b) cistransoid polyacetylene

(c) trans-cisoid polyacetylene

(d) polyparaphenylene

(e) polyparaphenylene vinylene

(f) polyparaphenylene xylylidene

(g) polybenzyl

(h) polyperinaphthalene

(i) polyperianthracene

(j) polypyrrole

(k) poly- $\beta, \beta$-dimethylpyrrole

(1) poly-N-methylpyrrole

(m) polythiophene

(n) polythiophene vinylene

図 1. 各種導電性高分子の化学構造

表 $1 . V E H$ 方法で計算した導電性高分子の

\section{バンドパラメータ}

(単位はeV, Egはバンドギャップ, BWはバンド幅, IPはイ オン化ポテンシャル, （）内数值は実測值である)

\begin{tabular}{|c|c|c|c|c|}
\hline & $E \mathrm{~g}$ & BW & IP & $\sigma$ \\
\hline \multicolumn{5}{|l|}{ polyacetylene } \\
\hline trans & $1.4(1.4)$ & 6.5 & $4.7(4.7)$ & 1200 \\
\hline cis-transoid & $1.5(1.7)$ & 6.4 & 4.8 & \\
\hline trans-cisoid & 1.3 & 6.5 & 4.7 & \\
\hline \multicolumn{5}{|l|}{ polyparaphenylene } \\
\hline $23^{\circ}$ torsion & $3.5(3.4)$ & 3.5 & $5.6(5.5)$ & 500 \\
\hline perpendicular & & 0.2 & 6.9 & \\
\hline polyparaphenylene vinylene & $2.5(\approx 3)$ & 2.8 & 5.1 & 2,700 \\
\hline polyparaphenylene xylylidene & 3.4 & 2.5 & 5.6 & \\
\hline polybenzyl & & 0.6 & 6.5 & $<10^{-5}$ \\
\hline polyperinaphthalene & 0.44 & 4.4 & 4.0 & \\
\hline polyperianthracene & 2.26 & 3.3 & 4.4 & \\
\hline polypyrrole & $3.6(3.2)$ & 3.8 & $3.9(4.0)$ & $40 \sim 100$ \\
\hline $\begin{array}{l}\text { poly- } \beta, \beta^{\prime} \text {-dimethylpyrrole } \\
\text { coplanar }\end{array}$ & 3.7 & 3.2 & 3.6 & 10 \\
\hline $\begin{array}{l}\text { poly-N-methylpyrrole } \\
\text { coplanar }\end{array}$ & 3.7 & 3.4 & 3.9 & $10^{-3}$ \\
\hline polythiophene & $2.0(2.2)$ & 2.6 & 5.0 & $10 \sim 100$ \\
\hline polythiophene vinylene & $1.6(2.2)$ & 2.5 & 4.9 & \\
\hline
\end{tabular}

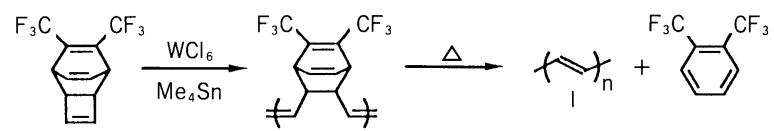

図 2.Durham-ポリアセチレン合成プロセス

子内部エネルギが低く，不溶，不融であった。この ことは加工性を欠き，応用面において大きな障壁で あった。しかし，1980年代中ごろから様々な可溶, 溶融性をもつ導電性高分子が開発された。高分子間 の相互作用を弱くさせる長い alkyl 側鎖を導入したポ リ（3-アルキルチオフェン）がその代表的な例であ $3^{4)}$ 。

一方, 合成プロセス研究によって導電性高分子構 造（ $\pi$ 共役構造）になる前の段階（前駆体）で加工で きるような合成法が開発された。ポリアセチレン合 成におけるDurham 法がその代表的な例であ る5)(図 2)。また，ポリフェニレンビニレン，ポリ チオフェンビニレン合成においても前駆体状態で加

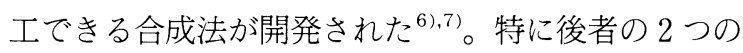
場合には，前駆体状態で $6 \sim 10$ 倍ぐらい延伸させる 


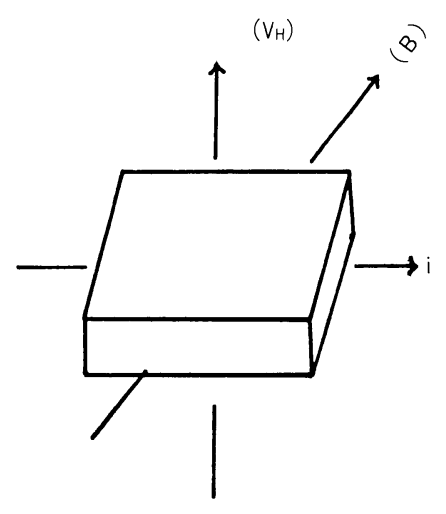

$\mathrm{i}$ : 電流, $\mathrm{V}_{\mathrm{H}}$ : ホール電圧, $\mathrm{B}$ : 磁界

図 3 ・ホール電圧測定方式

ことによって，延伸方向の導電率が $10^{3} \sim 10^{4} \mathrm{~S} / \mathrm{cm}$ と いう高い值を得ている ${ }^{8)}$ 。

\section{2 導電率を決める因子および測定法}

導電性高分子において電荷の移動は無機半導体と 同様に自由電子または正孔（ホール）によって行わ れる（自由電子および正孔の発現原理については後 述する)。またこれらキャリアは高分子鎖中を移動す るだけでなく，鎖と鎖間または高分子のミクロな集 合体（ドメイン）間をホッピングすることも知られ ている。このような事実から導電性高分子における 導電率のは次式(1)のようにキャリアの密度 $\mathrm{n}$ およびそ の移動度杧よって決められる。

$$
\sigma=\mathrm{nq} \mu
$$

（ q はキャリアの電荷，電子の場合 $1.602 \times 10^{-19} \mathrm{C}$ )

移動度 $\mu$ は単位電界当たりのキャリアの移動速度で ある。したがって $(\mathrm{cm} / \mathrm{s}) /(\mathrm{V} / \mathrm{cm})=$ $\mathrm{cm}^{2} \mathrm{~V}^{-1} \mathrm{~s}^{-1}$ の単位をもつ。キャリアの移動度および密 度はホール効果を利用する電流磁気効果の測定によっ て求めることができる。すなわち図 3 のように電流 が流れる方向に垂直に磁界 ( B ) を与え, 電流 ( i ) と 磁界の垂直方向に発生する電位（ $V_{H} ）$ を測定すると 式(2)によってホール係数 $\mathrm{R}_{\mathrm{H}}$ が求まる。

$$
\mathrm{V}_{\mathrm{H}}=\mathrm{R}_{\mathrm{H}} \times \frac{\mathrm{iB}}{\mathrm{d}}(\mathrm{d} \text { : サンプルの厚み })
$$

また式(3)によってキャリアの濃度 $\mathrm{n}$ が求められる。

$$
\mathrm{n}=\frac{1}{\mathrm{R}_{\mathrm{H}} \cdot \mathrm{q}}
$$

さらに式(1)と式(3)によって $\mu=\mathrm{R}_{\mathrm{H}} \sigma$ のように移動度 が求められる。
また半導体に強い磁界を加えると，その抵抗が増 加する磁気抵抗効果を用いてキャリアの密度および 濃度を求めることができる。ここではその式だけを 述べると次式(4)のと拈りである。

$$
\frac{(\rho(\mathrm{B})-\rho(\mathrm{O}))}{\rho(\mathrm{O})}=\mu^{2} \mathrm{~B}^{2}
$$

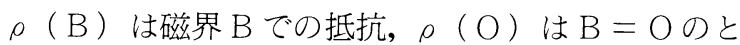
きの抵抗である。

導電性高分子の導電率の測定は導電率が低いとき $\left(<10^{-9} \mathrm{~S} / \mathrm{cm}\right)$ は二端子法, 高いときは端子と試 料との接触抵抗を受けずに測定できる四端子法が使 われる。図 4 の（a）はディスク型のサンプルによ く使われている四端子法であり，（b）はサンプルの 形状にかかわらず適用できるファンデルポー法であ る。単純な四端子法（a）では定電流（i）を外側の 2 つの端子からサンプルに流し, 内側の 2 つの端子 を用いて対応する電圧（V) を測定する。この場合 導電率は式(5)によって求められる。

$$
\sigma=\frac{\ln 2 \cdot \mathrm{i}}{\pi \cdot \mathrm{V} \cdot \mathrm{d} \cdot \mathrm{F}(\mathrm{d} / \mathrm{s})}
$$

$(\mathrm{d} / \mathrm{s}<0.4$ のとは $\mathrm{F}(\mathrm{d} / \mathrm{s})$ は 1$)$

ファンデルポー法では端子 $\mathrm{AB}$ 間に電流を与え， 端子 $\mathrm{CD}$ 間の電圧を測定して得られる抵抗 $\mathrm{R}_{\mathrm{AB}, \mathrm{CD}}$ と $\mathrm{AC}$ $\mathrm{BD}$ 対の抵抗 $\mathrm{R}_{\mathrm{AC}, \mathrm{BD}}$ を用いて次式(6)によって導電率を 求める。

$$
\sigma=\frac{2 \ln 2}{\pi \mathrm{d}\left(\mathrm{R}_{\mathrm{AB}, \mathrm{CD}}+\mathrm{R}_{\mathrm{AC}, \mathrm{BD}}\right)} \mathrm{g}
$$

$\mathrm{g}$ は $\mathrm{R}_{\mathrm{AB}, \mathrm{CD}}, \mathrm{R}_{\mathrm{AC}, \mathrm{BD}}$ に関する補正係数で $\mathrm{R}_{\mathrm{AB}, \mathrm{CD}} / \mathrm{R}$ $\mathrm{AC}, \mathrm{BD}$ が 1 〜 100 のときに 1 〜 の值をとる。

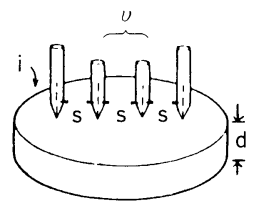

( a )

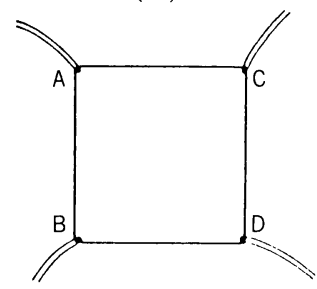

(b)

図 4，四端子法による導電率の測定 


\section{3 導電性高分子の導電機構}

導電性高分子の導電機構に対する理論は Heeger, Brédas など多くの人々によって研究，確立されてき たが，様々な異なる導電現象を明白に説明するには まだ不十分である。ここではポリアセチレンのよう な縮退している構造をもつ高分子に対応するソリト ンモデルと，ポリパラフェニレン，ポリピロールな どのように縮退していない構造をもつものに対応す るポーラロンモデルに関して簡単に紹介する。詳し くは文献を参照していただきたい ${ }^{9) ~ 11) 。 ~}$

transーポリアセチレン鎖の中には結合交替の不整 によって図 5 のようなラジカルを有する欠陷が生じ る。この欠陥は炭素3000に対して 1 つの割合で発生 する ${ }^{12)}$ 。これが中性ソリトンである。これに対応し て transーポリアセチレンのバンドギャップの中央に 新しい電子準位が生じ，スピン $1 / 2$ のラジカルに より占拠されている。電子受容体（A）あるいは電 子供与体（D）によってドーピングされるとこのラ ジカルが取り去られて正に荷電されたり，あるいは もう 1 つ電子が与えられて負に荷電された状態にな る。このような過程によって電荷キャリアが生じる。 ポリアセチレンとは違って, ポリパラフェニレン, ポリピロール，ポリチオフェンなどでは図 6 の（a）, ( a )’のように結合状態が異なる 2 つの構造をとる。 両者のポテンシャルエネルギは等しくない。基底状 態ではポテンシャルエネルギがキノイド型より約 0.4 $\mathrm{eV}$ ほど低い芳香族型になっている。ドーピングによっ てイオン化された状態になると, 分子がイオン化に
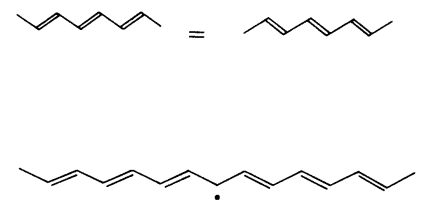

中性ソリトン $\left(\mathrm{S}^{0}\right)$
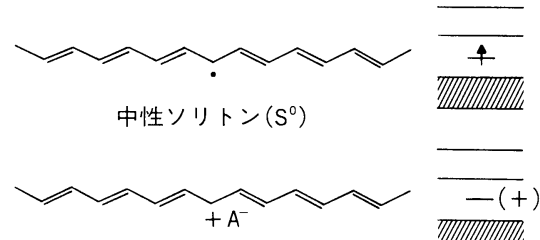

荷電ソリトン $\left(S^{+}\right)$

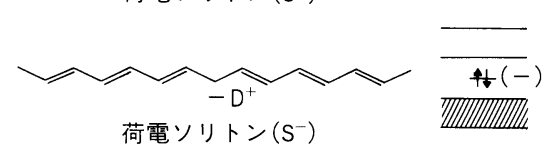

図 5 .trans-ポリアセチレンにおけるソリトン分子構造 とバンド構造の模式図
要するエネルギを小さくするようにポリマー鎖の一 部がキノイド構造になる（図 $6(\mathrm{~b}))$ 。これは芳香 族型よりはキノイド型の方がイオン化ポテンシャル が低く, 電子親和力が大きいためである。この状態 は格子のひずみをラジカルイオンとみなし，ポーラ ロンと定義される。

ドーピングの量が増加し， 2 個のポーラロンが 1 本のポリマー鎖中に存在するようになるとこれらが 結合して電荷対を形成する。これをバイポーラロン という（図6 (c))。

以上のようなソリトン，ポーラロンモデルはバン ド理論および磁気的性質の測定, 光学的吸収スペク トルの測定などで確かめられている。

\section{3. 導電性高分子の応用}

\section{1 二次電池}

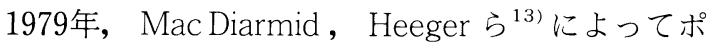
リアセチレンが電気化学的な方法で酸化還元を行う ことが発表された後，すぐにこの特徵を二次電池と

して応用する研究が開始された ${ }^{14)}$ 。

従来の電極素材においては電解質溶液への溶解性 の問題上，その材料選択にかなりの制限があったが， 導電性高分子の大部分はほとんどの溶媒に不溶であ ることが 1 つ利点となっている。理論的には高分 子電極で構成された二次電池には従来の二次電池と 比較して表 2 のような長所があげられる ${ }^{15)}$ 。

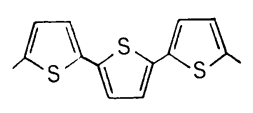

(a) 芳香族型

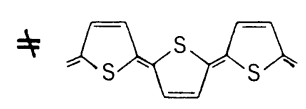

$($ a) キノイド型

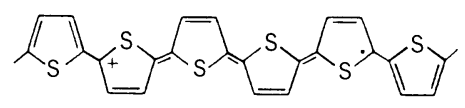

(b)

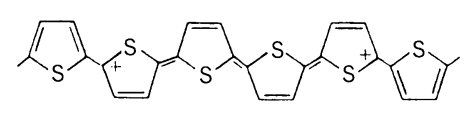

(c)

図 6 . ポリチオフェン(a)におけるポーラロン(b)とバイポ ーラロン(c)状態 
表 2 . 高分子二次電池の期待性能

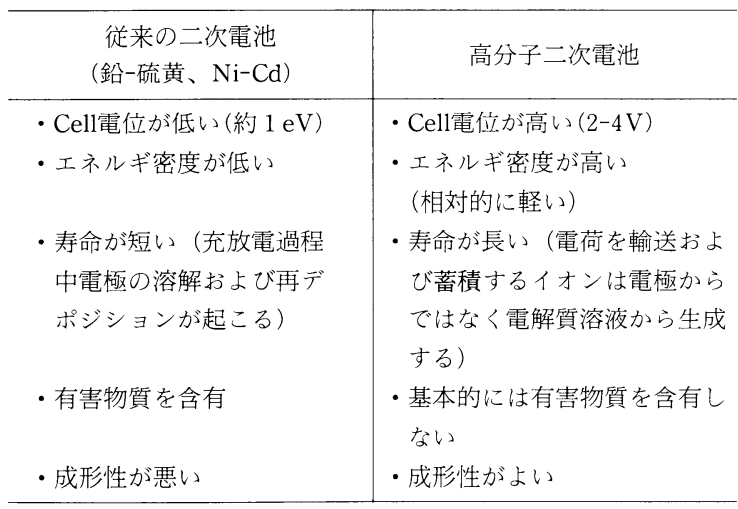

導電性高分子の二次電池の電極材料としての応用 はほとんどが正極用である。もちろんポリアセチレ ン，ポリチオフェンなどは容易にカチオンドーピン グされるから負極としての利用可能性はあるが，現 用の $\mathrm{Li}$ あるいはその $\mathrm{Al}, \mathrm{Si}$ などとの合金と比較し て出力電圧が低く，また低電圧であるため二次電池 としての特性はあまり良くない。表 3 に様々な導電 性高分子電極の電気化学的特性值を従来の電極と比 較して示す ${ }^{15)}$ 。

先に述べたようにポリアセチレンの酸化還元特性
の可逆性の発見が導電性高分子の二次電池用電極素 材への応用の研究に火をつけたわけだが，実用面に おいてポリアセチレンは解決しなければならない問 題点を多くもっている。ポリアセチレンは電荷保持 能力が低く熱的安定性にも欠けている。さらに，加 工性および空気中安定性が悪いことは実用面におい て大きな障壁である。これらの理由から，ポリア二 リン ${ }^{16 \mathrm{a})}$, ポリピロール ${ }^{16 \mathrm{~b})}$, ポリパラフェニレン16c) などが電極用として最も積極的に研究された。これ らはポリアセチレンと比べると容易に作製でき，ま た空気中の安定性も良い。さらに製造時のコスト面 でみても有利である。

これらの中でポリアニリンとポリピロールが日本 の Bridgestone - Seiko 社およびドイツの BASF / VARTA 社によってすでに商品化されている。 BASF /VARTA 社によって開発された二次電池は 電気化学重合法で合成したポリピロールを正極に, Li を負極に用いている。この二次電池の充放電時の 電極反応は図 7 のようになる ${ }^{15)}$ 。ポリピロール電極 の半電池充放電曲線は図 8 である ${ }^{15)}$ 。この電池の電 圧範囲は $\mathrm{Li} / \mathrm{Li}^{+}$に対して2-4 Vである。

Bridgestone - Seiko社が開発したボタン型の二次電

表 3.さまざまな電極の特性

\begin{tabular}{|c|c|c|c|c|}
\hline 材 & $\begin{array}{c}\text { 電 圧 } \\
(\mathrm{V})\end{array}$ & 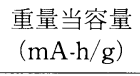 & $\begin{array}{l}\text { 体積当容量 } \\
\left(\mathrm{mA}-\mathrm{h} / \mathrm{cm}^{3}\right)\end{array}$ & $\begin{array}{c}\text { サイクル寿命 } \\
\text { (初期容量の } 80 \% \text { ) }\end{array}$ \\
\hline $\mathrm{Li}$ & 0 & 3830 & 2040 & $\longrightarrow$ \\
\hline $\begin{array}{l}\text { ポリアセチレン- } \mathrm{BF}_{4} \\
{\left[\mathrm{CH}\left(\mathrm{BF}_{4}\right)_{0.09}\right]}\end{array}$ & 3.5 & 116 & 140 & 10 \\
\hline $\begin{array}{l}\text { ポリアセチレン-Li } \\
{[\mathrm{CHLi0.18}]^{\mathrm{a}}}\end{array}$ & 1.0 & 339 & 423 & 90 \\
\hline $\begin{array}{l}\text { ポリアニリン }-\mathrm{BF}_{4} \\
{\left[\mathrm{C}_{6} \mathrm{H}_{5} \mathrm{~N}\left(\mathrm{BF}_{4}\right)_{0.5}\right]}\end{array}$ & 3.4 & 100 & 129 & 200 \\
\hline $\begin{array}{l}\text { ポリピロールー- } \mathrm{BF}_{4} \\
{\left[\mathrm{C}_{4} \mathrm{H}_{3} \mathrm{~N}\left(\mathrm{BF}_{4}\right)_{0.33}\right]}\end{array}$ & 3.2 & 94 & 124 & 200 \\
\hline $\begin{array}{l}\text { ポリパラフェニレンーLi } \\
{\left[\mathrm{C}_{6} \mathrm{H}_{4} \mathrm{Li} 0.5\right]^{\mathrm{a}}}\end{array}$ & 0.7 & 169 & 220 & 200 \\
\hline $\begin{array}{l}\operatorname{Lix}_{x} \operatorname{MoS}_{2} \\
(\Delta \mathrm{X}=0.8)\end{array}$ & 1.8 & 128 & 600 & 200 \\
\hline $\begin{array}{l}\mathrm{Li}_{x} \mathrm{CoO}_{2} \\
(\Delta \mathrm{X}=0.5)\end{array}$ & 4.0 & 137 & 640 & 80 \\
\hline $\begin{array}{l}\operatorname{Li}_{x} \mathrm{Al} \\
(0<\mathrm{X}<1)^{\text {a }}\end{array}$ & 0.4 & 788 & 1320 & 3 \\
\hline $\begin{array}{l}\mathrm{Na} \times \mathrm{Pb} \\
(1<\mathrm{X}<3.75)^{\mathrm{a}}\end{array}$ & 0.2 & 251 & 1300 & 2 \\
\hline
\end{tabular}

※ a : 負極 


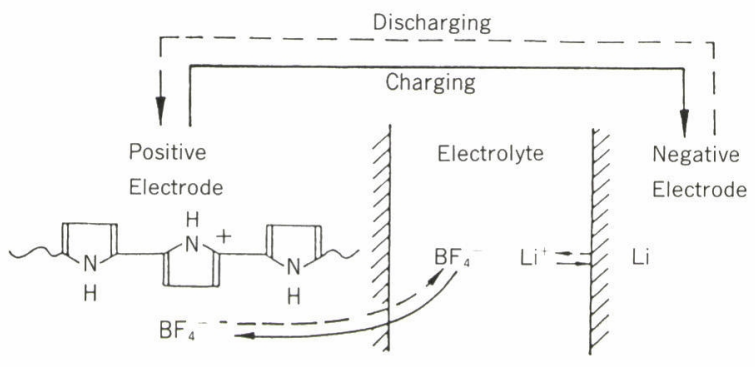

図 7 .ポリピロール Li 2 次電池の充電および放電時の 電気化学反応

池は $\mathrm{Li} / \mathrm{Al}$ 合金を負極とし，正極として分子量が 10000-80000のフィブリル状ポリアニリンで構成され

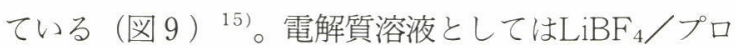
ピレンカーボネイト，1，2-ジメトキシエタンを使っ ている。放電時の回路電圧は2 $.5 \mathrm{~V}$ でサイクル寿命は 100\%の放電時（4 mAh）に対し200回以上，25\%で は2000回以上となっている。また自己放電性は 3 か 月放置で容量の約 $15 \%$ にどまる。このような二次 電池はエネルギ密度が小さいので, 少量のエネルギ が消費される電子機器のバックアップ用電源として の用途に適する。例えば, コンピュータ, 電卓, マ ルチメータなどのメモリー用電源などがある。

\section{2 コンデンサ}

先に述べたように導電性高分子は電子が非局在化 している共役構造をとっているため，異常に大きな 誘電率が観測されることがある。例えば，ポリアセ チレンは $\mathrm{IrCl}_{6}{ }^{-}$を0.05mol\%以上ドープしたとき 10000 のオーダーの誘電率をもち， $0.03 \mathrm{~mol} \%$ ドープにお いても 700 前後の值で, 周波数依存性はほとんどもた

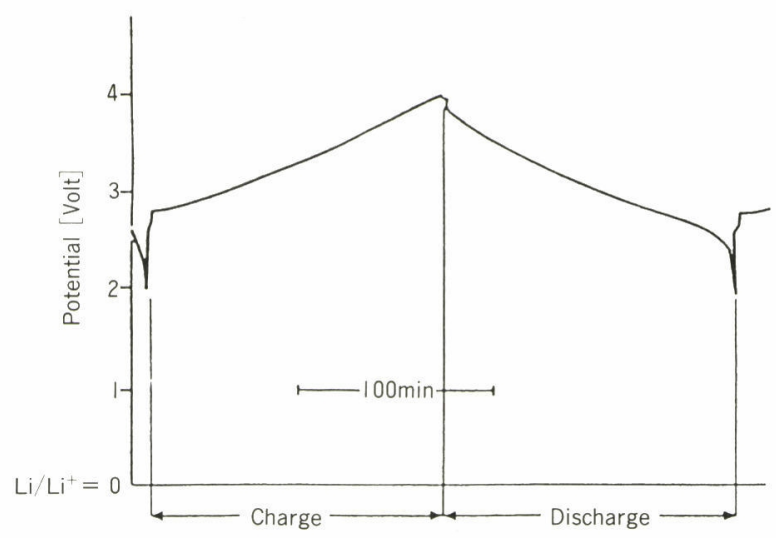

図 8.ポリピロール/Li 2 次電池の充電および 放電特性曲線

(電解質溶液：0.5 $\mathrm{M} \mathrm{LiClO}_{4}$ を含むプロピレンカーボネイト)

ない。また $\mathrm{ClO}_{4}{ }^{-}$をドープしたポリピロールは誘電率 の温度依存性の測定から室温で強誘電体であること が示唆されている。このように導電性高分子の特異 な強誘電特性は, 小型大容量コンデンサへの応用と して期待されるが，現段階までは強誘電特性の応用 よりは主に導電特性を応用した製品化への研究が行 われてきた。

一般的に使われている電解質コンデンサ（図10） では，その導電プロセスがイオンによるため高周波 領域での応答速度が遅くなり，インピーダンスが急 激に変化する。また低い温度においても電解質液の 粘度が高くなるためイオンの動きが遅くなり, 電流 が減少するような欠点がある。この問題点を改良す るため液体電解質の代わりに固体電解質を用いた夕 ンタルコンデンサの開発，また有機導電体であるテ

Cathode can

Anode (Li-Al alloy)

Cathode (Polyaniline)

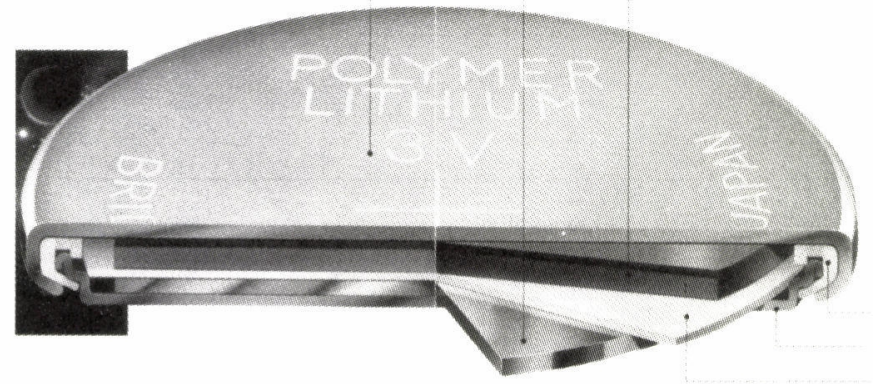

Gasket

Anode cap

Separator

図 9.Bridgestone-Seiko社のポリアニリン-Li 2 次電池の構造 


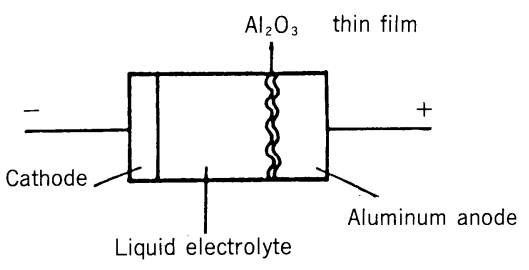

図10．電解質コンデンサの構造

トラシアノキノジメタン ( TCNQ ) コンプレックス を正極材料としたコンデンサの開発などの努力がな されていた。後者の TCNQ コンプレックス電解質 $\mathrm{Al}$ コンデンサはタンタルコンデンサよりも優れた周波 数安定性をもっているが，製作過程中の自動固着工 程での高温に対する安定性が悪いという欠点がある。

ポリピロールは導電性高分子中では相対的に高い 導電性および安定性を有し，また製造の容易性およ び $\mathrm{Al}_{2} \mathrm{O}_{3}$ に対するよい接着特性などの点から，この分 野への応用が検討されてきた。最近では，Marconと Japan Carlit 社の共同開発によって商品化段階にまで 至っている。このコンデンサの構造は図11のように $\mathrm{Al}$ 負極が $\mathrm{Al}_{2} \mathrm{O}_{3}$ とポリピロールによって囲まれてお り，ポリピロールと正極との電気的接触性を向上さ

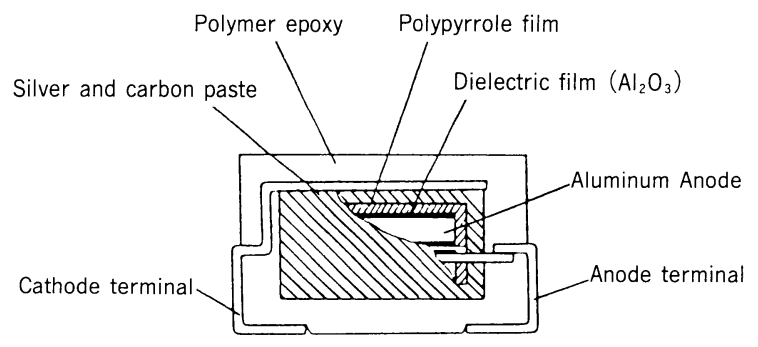

図11. ポリピロールコンデンサの断面図

せるためにカーボンペーストまたは銀ペーストを用 いている15)。

他の電解質コンデンサと比較した，インピーダン スの周波数依存特性および温度依存特性は図 12 と図

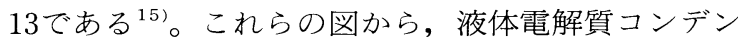
サの容量は約 $4 \times 10^{3} \mathrm{~Hz}$ の周波数から減少しはじめ るが，ポリピロールコンデンサでは $1 \mathrm{MHz}$ まで安定 であることがわかる。また, 温度変化に対する安定 性も優れていることがわかる。さらにポリピロール は過電圧によって絶縁体状態になる特性をもつこと から, 洩れ電流 (leakage) によるコンデンサのダメー ジを防ぐ自己復元特性を示すのも 1 つの特徴である。

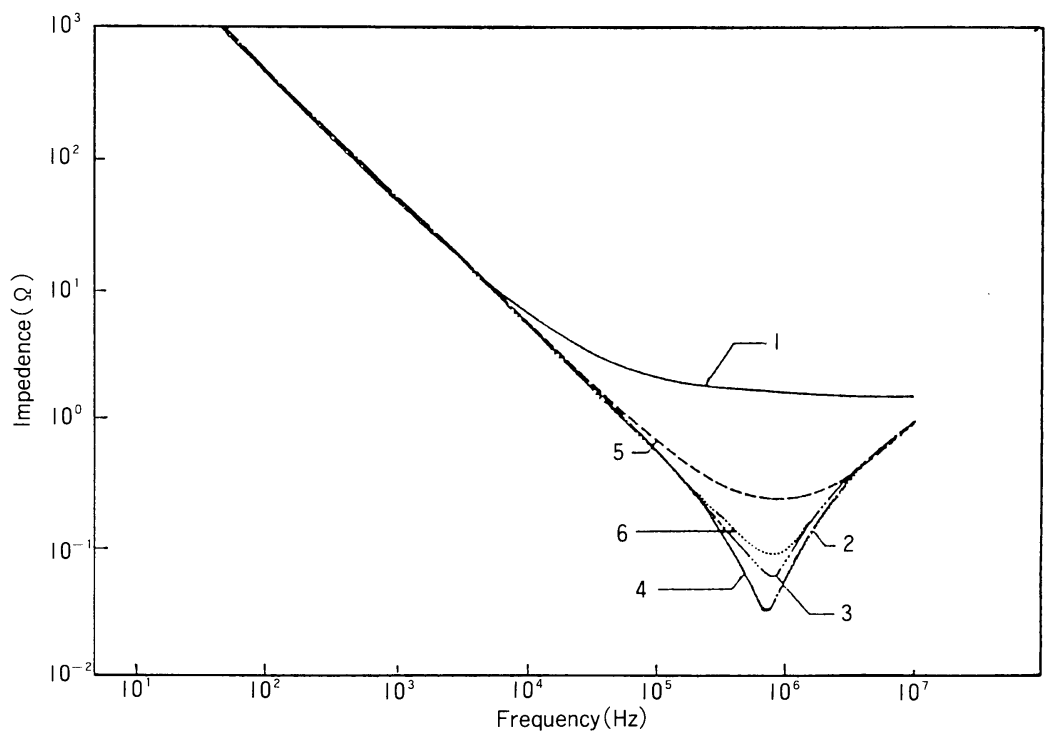

(1.小型 $\mathrm{Al}$ 電解質コンデンサ, 2. 金属フィルムコンデンサ,

3. 導電性高分子-Al電解質コンデンサ, 4.積層セラミック

コンデンサ, 5.タンタル固体電解質コンデンサ,

6.TCNQコンプレックス電解質コンデンサ)

図12. 各種コンデンサのインピーダンスの周波数依存性 
ポリピロールコンデンサの予想寿命は約10000時間,

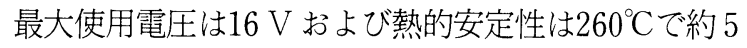
秒である。Marcon 社は月平均100億個のコンデンサ を生産しているが, そのうち10億個をポリピロール コンデンサに代替することを計画している ${ }^{15)} 。$

\section{3 接合デバイスおよびトランジスタ}

$\mathrm{AsF}_{5}$ やハロゲン（ $\left.\mathrm{I}_{2}, \mathrm{Br}_{2}\right)$ などの電子受容体ある いは Li， Naなどの電子供与体を用いてポリアセチ レンをドープすることによって，正孔（ $\mathrm{p}$ 型）ある いは自由電子 ( $\mathrm{n}$ 型) が形成され, その導電性が数 桁も上昇するとともに, $\mathrm{AsF}_{5}$ をドープした $\mathrm{p}$ 型ポリ アセチレンと $\mathrm{Na}$ をドープした $\mathrm{n}$ 型ポリアセチレンの 薄膜を張り合わせるとダイオード特性を示すことが

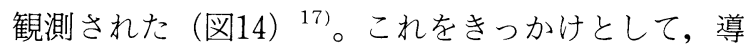
電性高分子と金属や無機半導体との接合特性が広範 囲に調べられた。その結果， $\mathrm{n}$ 型半導体と多くの導 電性高分子が良好な接合特性を示すことがわかった。 一般的に, 接合素子への応用において導電性高分子 の長所は仕事関数が大きいことにある。例えばドー プしたポリアセチレンの仕事関数は $5.7 \mathrm{eV}$ で，金（5.3 $\mathrm{eV})$ ，白金 $(5.7 \mathrm{eV})$ に匹敵する。

接合デバイスへの応用研究においても, 最初はポ リアセチレンを中心に行われていたが，ポリアセチ レンに引き続いて発見されたポリピロールやポリチ

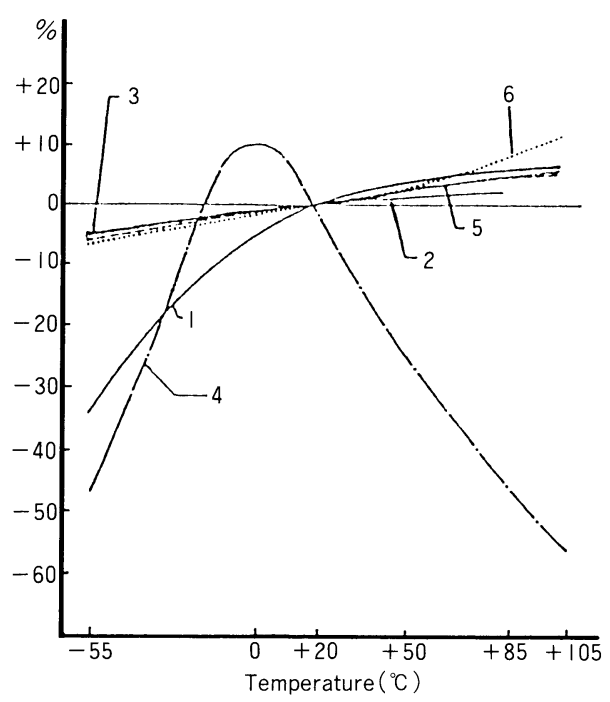

図13. 各種コンデンサのインピーダンスの温度依存性 (初期値に対する百分率)

(各番号に対応するコンデンサは図12と同じである)

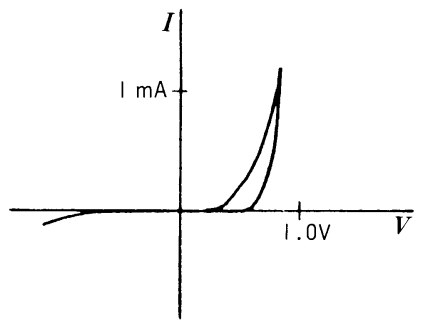

図14.p型 $(\mathrm{CH}) \times / \mathrm{n}$ 型 $(\mathrm{CH}) \times$ 接合の電流一電圧特性

オフェンなどに研究の重点が移ってきた。これはこ れらのポリへテロ環化合物の空気に対する安定性, ある程度の精密な製膜の可能性，より明瞭な電気化 学活性などによるものである。

さらに導電性高分子同士の接合素子の研究も行わ れている。しかし $\mathrm{p}$ 型と $\mathrm{n}$ 型の導電性高分子同士の $\mathrm{p}-\mathrm{n}$ 接合デバイスの場合にはドーピングによって導 入された電子受容体イオン $\left(\mathrm{A}^{-}\right)$と電子供与体イオ ン $\left(\mathrm{D}^{+}\right)$の拡散によって $\mathrm{p}$ 型と $\mathrm{n}$ 型との接合面で $\mathrm{A}^{-}$ $\mathrm{D}^{+}$の塩を形成し，接合特性が失われることが十分予 想される。このような界面補償効果を排除させるの がポリアセチレン/ポリ（N-メチルピロール）接合， あるいはポリピロール/ポリチオフェン接合素子の ようなへテロ接合素子である。前者の場合はポリア セチレン膜が, また後者の場合はポリチオフェンが 無ドープあるいは低ドープ状態に保たれたままで， ポリ（N-メチルピロール）およびポリピロールがドー プされた状態になっている。図15にポリチオフェン／ ポリピロール接合素子の構造および電流-電圧 $(\mathrm{I}-\mathrm{V})$ 特性を示す ${ }^{18)}$ 。良好な整流特性があることがわかる。 一方，当然のことながらこれらの材料を用いた FET (電界効果トランジス夕) 素子の研究も活発に行わ れてきた。図16に電解重合法で合成したポリチオフェ ン膜をチャネル層として用いた FET の構造およびI$\mathrm{V}$ 特性を示す ${ }^{19)}$ 。最適な FET 素子特性が得られるの はポリチオフェンの導電性が $10^{-8} \mathrm{~S} / \mathrm{cm}$ のきであ ると報告されている。この FET の I-V 特性は高 $\mathrm{V}_{\mathrm{DS}}$ 領域においてIS飽和がみられるなど，理想的な FET 特性とみなされ, 電流はゲート電圧により 3 ケ夕ま で変化させることができる。しかし導電性高分子の FET 素子の最大の課題は動作電流レベルが小さいこ とであり，実用化のためには電流レベルをさらに 2 


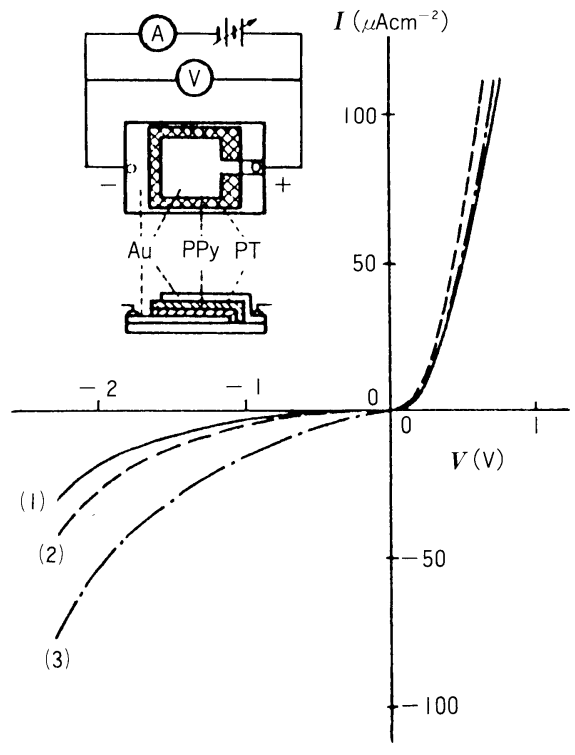

$\mathrm{PPy}$ :ポリピロール、PT：ポリチオフェン

図15.電位3.2V(1)，3.4V(2)，3.6V(3)でドープした $\mathrm{Au} / \mathrm{PPy} / \mathrm{PT} / \mathrm{Au}$ へテロ接合素子の電流一電圧特性

3 桁大きくさせなければならないと指摘されている。

\section{4 透明電極}

導電性高分子の光吸収は, ドーピングのメカニズ ムにより大きく影響される。前節で示したように， ポリマーの種類によって荷電ソリトン，ポーラロン， バイポーラロンといった状態が形成される。このと き実質的にポリマーの共役鎖が切断され，この部分 がイオン化する。したがってドープ前の吸収とは異 なった状態（高エネルギ側へのシフト）に変化する と同時に，電荷移動に基づく新しい吸収が出現する。 もし理想的な位置でのみ，イオン化を起こし，かつ ドーパントの吸収がないと仮定すれば“可視領域で の空”を作ることができるかもしれない。ポリアセ チレン，ポリピロールなどではドーピングによって そのバンド間吸収強度が徐々に減少し，バンド内に 生成した新しい準位によるより低エネルギ波の吸収 が増大する。未ドープ状態で可視領域あるいはそれ よりも長波長領域に該当するバンドギャップをもつ 高分子が合成できれば，ドーピングにより導電性を もつ透明高分子の製作も可能である。実際，小林ら によって電気化学法で合成されたポリイソチアナフ テンは未ドープ状態で $1.0 \mathrm{eV}$ という非常に小さいバ ンドギャップをもち，Br+などによってドープされる
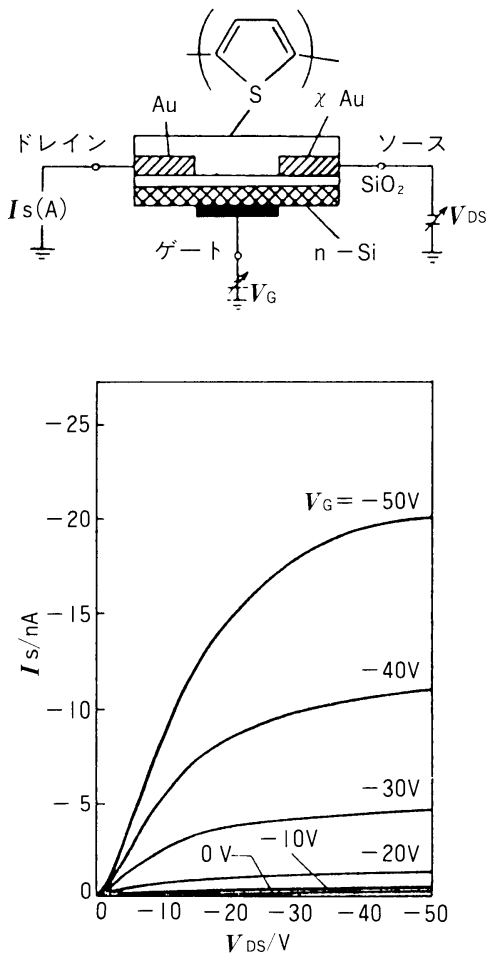

図16.ポリチオフェンを半導体層として用いた FET素子構造と光の特性

につれて吸収全体が赤外領域へシフトする。そして, 約 $50 \mathrm{~S} / \mathrm{cm}$ の導電性をもつ薄い黄色を呈する透明膜 が得られることが報告されている ${ }^{20)}$ 。

一方, 著者らはポリピロールを固気界面で化学重 合させることにより透明性の良い膜を得た。これは 金, 銀の透明導電膜のように光の全反射・吸収域で も膜が非常に薄い場合には光のすべてが反射されず に透過することと類似な原理に基づくと思われる。 図17と表 4 に固気界面でのポリピロールの化学重合 プロセスおよび得られた（ポリピロール/バイン ダーポリマー）フィルムの導電性および透過率の比 較を示した ${ }^{21)}$ 。この透明ポリピロールを圧電性ポリ マー（ポリフッ化ビニリデン系）をはさむ形で電極 として用い, 透明スピーカーの試作に成功した (図18) 15)。

\section{5 電気めっき}

化学重合法によって合成されたポリピロールは電 気化学法によって合成されたポリピロールと比べて ドーパントを抜き出し（脱ドープ）にくい。

この特性は電気めっきにおいては有用である。す 


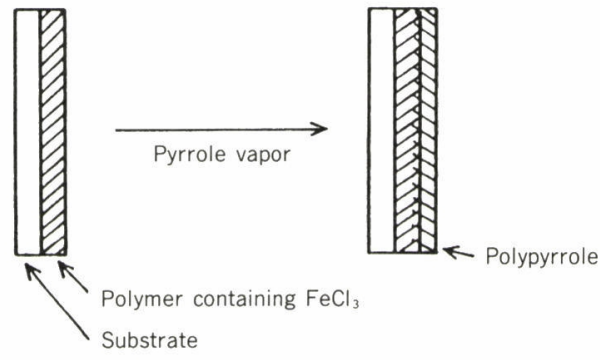

図17.ピロールの気相重合プロセス

なわち，金属をめつきするプラスチックの表面に化 学重合法で作られたポリピロールをコーティングし てこれを負極として用いることができる。このポリ ピロールの脱ドーピング速度はかなり遅いので電気 めっきが進行する間しばらくは負極としての働きが できる。ポリピロールはほとんどのプラスチックへ の吸着性がよいし, 表面がある程度粗いので銅など の金属が良く吸着し，めつきがきれいに得られる。 図19にこの方法を用いて試作された銅めっきパター ンを示す。

\section{6 光の他}

以上, 試作段階まで行われた導電性高分子のいく つかの応用例を紹介してきた。上記の応用例以外に も導電性高分子の特性を生かす応用分野は無限に存 在する。ここではいままでに述べてきた以外のいく つかの研究内容を示す。

基本的な導電性特性を利用した電磁波シールド用 材料や異方性導電材料に関する研究が行われている。 導電性高分子はドーパントイオンの可逆的な出入り に伴うエレクトロクロミック現象を示す ${ }^{22)}$ 。また, ポリ（3-アルキルチオフェン）のような可溶可融性 導電性高分子の場合には, 溶媒や熱的条件によって 分子のコンフォメーションの変化が起こり, それに

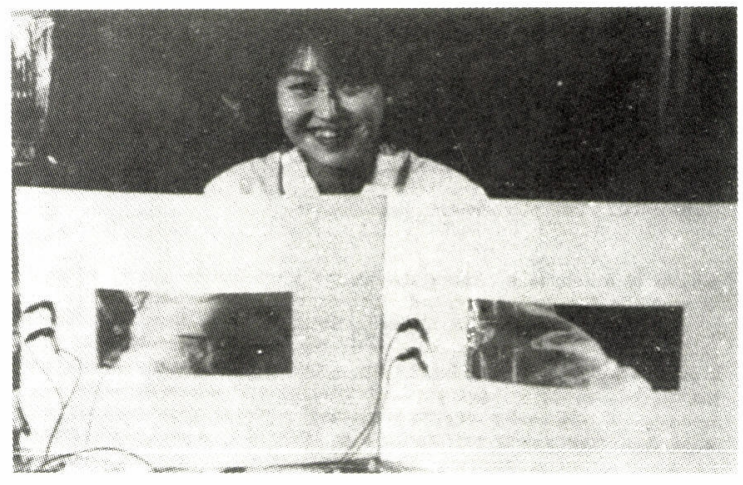

図18. 透明ポリピロールを電極として用いた 透明スピーカー

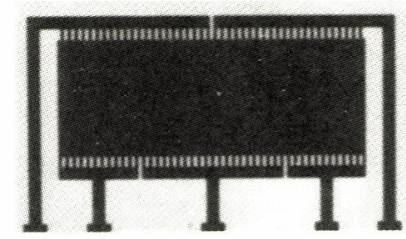

(a)ポリピロールが塗布された状態

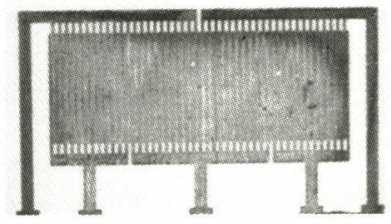

(b) 銅めつき後の状態

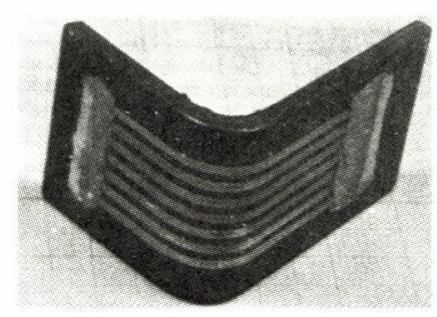

(c) 湾曲部への銅めつき

図19. 絶縁体表面への銅めつきの例

表 4 . 各複合フィルムの導電率と透過率

(波長 $550 \mathrm{~nm}$ ，フィルムの厚み $2 \mu \mathrm{m}$ )

\begin{tabular}{|c|c|c|c|c|}
\hline $\begin{array}{l}\text { Binding } \\
\text { polymer }\end{array}$ & $\begin{array}{l}\text { Oxidizing } \\
\text { agent }\end{array}$ & $\begin{array}{c}\text { Binding polymer/Oxidizing agent } \\
\text { ratio }\end{array}$ & $\begin{array}{l}\text { Conductivity } \\
(\mathrm{S} / \mathrm{cm})\end{array}$ & $\begin{array}{c}{ }^{*} \text { Transmittance } \\
(\%)\end{array}$ \\
\hline PVA & $\mathrm{FeCl}_{3}$ & $98 / 2$ & 1 & 80 \\
\hline "n & $n$ & $70 / 30$ & 10 & 27 \\
\hline PMMA & "1 & " & $3 \times 10^{-1}$ & 40 \\
\hline PVAc & " & " & $4 \times 10^{-2}$ & 30 \\
\hline PVC & " & " & $9 \times 10^{-2}$ & 22 \\
\hline PAN & " & "1 & $1 \times 10^{-3}$ & 20 \\
\hline
\end{tabular}


伴いソルバトクロミックやサーモクロミック現象を 示す ${ }^{23), 24)}$ 。そこでこれらの現象を利用した情報記録・ 記憶材料などの研究も行われている ${ }^{25)}$ 。未ドープ状 態の導電性高分子はアンモニア, $\mathrm{Br}_{2}$ や $\mathrm{SO}_{3}$ などの酸 化還元性の高い気体にドープされると導電性の変化 および色の変化が起こる特徵を利用して, これらの 気体感知センサーとして応用できる ${ }^{26)}$ 。また, ドー パント挿入特性を利用して機能性物質（酵素）など を担持させることにより，グルコースなどの糖感知 センサーの研究も行われている ${ }^{27)}$ 。さらに， $\pi$ 共役系 を含む導電性高分子が大きな三次非線形光学効果を もつことから, 光双安定スイッチ, 光コンピュータ への応用も期待できる ${ }^{28), 29) 。 ~}$

さらに，銅に匹敵する導電率をもつ高分子材料が できているので，これをプリント配線板に応用する ことも将来の可能性として残されている。今後とも 導電性高分子は軽くて丈夫であるというメリットを 活かすような研究を続ければ，意外な応用も開けて くるであろう。

\section{4. おわりに}

導電性高分子は, 従来の無機材料にない優れた性 質や特徵を備えていることから, 各種デバイスや電 池への応用の研究が活発に行わ机ているが, 本格的 な応用には，その構造の乱れおよび不均一さなどの 解決すべき問題が数多くある。

しかし導電性高分子の特徵を十分いかせば，まっ たく新しい概念のデバイス等の出現が期待できると 考えられる。

(1991.7.25-受理)

\section{文献}

1) T. Ito, H. Shirakawa, S. Ikeda, J. Polym. Sci. Polym. Chem. Ed., 12, 11, 1974

2) C. K. Chiang, C. R. Fincher, Jr., Y. W. Park, A. J. Heeger, H. Shirakawa, E. J. Louis, S. C. Gau, A. G. MacDiarmid, Phy. Rev. Lett. , 39, 1098, 1977

3 ) (a) J. L. Brédas, 導電性高分子の理論的設計, 新 導電性高分子材料 (雀部博之監修), 東京, シーエム シー, 1987 (b) J. L. Brédas,R. L. Elsenbaumer, R. R. Chance, and R. Silbey, J. Chem. Phys., 78, 5656, 1983

4 ) (a) K. Y. Jen, R. Oboodi, R. L. Elsenbaumer, Polym. Materials: Sci. Eng., 53, 79, 1985

(b) M. Sato, S. Tanaka, and K. Kaeriyama, J. Chem. Soc., Chem. Commun., 873, 1986

5 ) (a) J. H. Edwards, W. J. Feast, and D. C. Bott,Polymer, $25: 395,1984$

(b) W. J. Feast, and J. N. Winter, J. Chem. Soc., Chem. Commun., 202, 1985

6 ) (a) D. R. Gagnon, J. D. Capistran, F. E. Karasz, and R. W. Lenz, Polym. Bull., 12, 293, 1984

(b) I. Murase, T. Ohnisi, J. Noguchi, and M. Hirooka, Polym. Commun., 25:327, 1984

7 ) (a) K.-Y. Jen, M. Maxfield, L. W. Shacklette, and R. L. Elsenbaumer, J. Chem. Soc., Chem. Commun., 309, 1987

(b) I. Murase, T. Ohnisi, J. Noguchi, and M. Hirooka, Polym. Commun., 28:229, 1987

8 ) 大西敏博, 野口公信, 中野強, 弘岡正明, 村瀬一基, 第 9 回次世代産業基盤技術シンポジウム一高機能性 高分子材料一，予稿集（I ），201～224，1991

9 ) A. J. Heeger, ソリトン, ポーラロン, バイポーラ ロン：導電性高分子における非線形励起と荷電状態, 新導電性高分子材料 (雀部博之監修), 東京, シーエ ムシー，1987

10) R. R. Chance, D. S. Boudreaux, J. L. Brédas, and R. Silbey, Solitons, Polarons, and Bipolarons in Conjugated Polymers, Handbook of Conducting Polymers (edited by J. A. Skotheim), vol. 2, New York, Marcel Dekker, 1986

11）吉村進, 導電性ポリマー, 高分子学会, 高分子新素 材One Point -5 , 東京, 共立, 1987

12）白川英樹, 山邊時雄, 合成金属, 東京, 化学同人, 1980

13) P. J. Nigrey, A. G. MacDiarmid, and A. J. Heeger, J. Chem. Soc., Chem. Commun., 1979 : 594, 1979

14) P. J. Nigrey, D. MacInnes, Jr., D. P. Nairns, 
A. G. MacDiarmid, and A. J. Heager, J. Electrochem. Soc., 128:1651, 1981

15) A. Techagumpuch, H. S. Nalwa, and S. Miyata, Promising Applications of Conducting Polymers, Electroresponsive Molecular and Polymeric Systems (edited by T. A. Skotheim), New York, Marcel Dekker, 1991

16) (a) A. G. MacDiarmid, S. L. Mu., N. L. D. Somasiri, and W. Wu, Mol. Cryst. Liq. Cryst., in $121: 187,1985$

(b) K. Kaneto and K. Yoshino, Kinou Zairyou (Jpn), 4, 8, 1984

(c) L. W. Shacklette, R. L. Elsenbaumer, R. R. Chance, J. M. Sowa, D. M. Ivory, G. G. Miller, and R. H. Baughman, J. Chem. Soc., Chem. Commun., 1982: 361, 1982

17) C. K. Chiang, S. C. Gau, C. R. Fincher, Y. W. Park, A. G. MacDiarmid, and A. J. Heeger, Appl. Phys. Lett., 33, 18, 1978

18) K. Kaneto, S. Takeda, and K. Yoshino, Jpn. Appl. Phys., 24, L553, 1985

19）肥塚裕至，高分子，38巻，10月号，964，1989
20) M. Kobayashi, N. Collaneri, M. Boysel, F. Wudl, and A. J. Heeger, J. Chem. Phys., 82, 5717, 1985

21）田坂茂，宮田清蔵，透明導電性高分子，新導電性高 分子材料 (雀部博之監修), 東京, シーエムシー, 1987

22) A. F. Diaz, J. I. Castillo, J. A. Logan and W. Y.Lee, J. Electroanal. Chem., 129, 115, 1981

23) S. D. D. V. Rughooputh, S. Hotta, A. J. Heeger and F. Wudl, J. Polym. Sci. Polym. Phys., 25, 1071, 1987

24) O.Inganäs and G. Gustafsson, Synth. Met., 37, 195, 1990

25) K. Yoshino, Synth. Met., 28, C669, 1989

26) M. R. Willis, K. J. Markland, M. R. Fahy, Synth. Met., 28, C781, 1989

27) P. N. Bartlett and R. G. Whitaker, J. Electroanal. Chem., 224, 37, 1987

28) F. Kajzar, S. Eternad, G. L. Baker and J. Messier, Solid State Commun., 63, 1113, 1987

29) P. N. Prasad, J. Swiatkiewicz and J. Pfleger, Mol. Cryst. Liq. Cryst., 160, 53, 1988

\section{既刊出版物頒布のご案内（送料は別途実費）}

・セミナーテキスト

第 4 回『小径スルーホールの加工技術』

B 5 判 36 頁 1 部 $=1,000$ 円

第 5 回『新しいPWB製造技術の動向』

B 5 判 59 頁 1 部 $=1,000$ 円

第 6 回『プリント配線板の新技術動向』

B 5 判 39 頁 1 部 $=1,000$ 円

第 8 回『ED斿よび液状レジスト塗布方法の動向』

B 5 判 48 頁 1 部 $=1,000$ 円

第 9 回『EMI (電磁波障害) とプリント回路』

B 5 判 56 頁 会員 $=1,000$ 円 非会員 $=1,500$ 円

第10回『ファインパ夕ーンの検査技術と品質保証』

B 5 判 71 頁 会員 $=1,000$ 円 非会員 $=1,500$ 円
-学術講演大会論文集（第 1 回，3 回論文集は品切れ）

第 2 回（1987年12月 8～9日）

B 5 判 134頁 会員 $=3,000$ 円 非会員 $=5,000$ 円

第 4 回（1989年11月28～29日）

B 5 判 180 頁 会員 $=3,000$ 円 非会員 $=5,500$ 円 第 5 回（1990年11月20～21日）

B 5 判 174頁 会員 $=3,500$ 円 非会員 $=5,500$ 円

・『サーキットテクノロジ』第 1 号〜第 29 号

B 5 判 会員 $=1,000$ 円 非会員 $=1,500$ 円

-『高密度パターンの大量複製技術研究部会』活動報告書 B 5 判 57 頁 1 部 $=500$ 円

・プリント回路学会 5 周年記念セミナーテキスト 『高密度実装時代のプリント回路技術』

B 5 判 104 頁 会員 $=1,500$ 円 非会員 $=2,000$ 円

○購入ご希望の方は学会事務局までお問い合わせ下さい。 